\title{
Persistent hypoxaemia following pneumonia unmasking hepatopulmonary syndrome
}

\author{
Meraj Ondhia 주, Sara Mohamed, Sushil Agarwal
}

Respiratory Medicine, Glenfield Hospital, Leicester, UK

Correspondence to Dr Meraj Ondhia; ondhiam@gmail.com

Accepted 22 May 2020

\section{DESCRIPTION}

A 44-year-old male was admitted to the respiratory unit with a history of worsening dyspnoea, productive cough and fever. He was an active smoker with a background of Child-Pugh class A alcoholic cirrhosis and previous intravenous drug use. On admission, he was feverish, tachypnoeic and was requiring an $\mathrm{FiO}_{2}$ of $60 \%$ to maintain oxygen saturations $>94 \%$. Crepitations were heard throughout the right lung; cardiovascular and abdominal examinations were normal. Laboratory tests showed a neutrophilia $\left(8.9 \times 10^{9} / \mathrm{L}\right)$, thrombocytopaenia $\left(45 \times 10^{9} / \mathrm{L}\right)$, normal haemoglobin $(130 \mathrm{~g} / \mathrm{L})$ and liver biochemistry. Arterial blood gas demonstrated hypoxaemia; $\mathrm{PaO}_{2} 8.79 \mathrm{kPa}$ on $60 \%$ oxygen and $\mathrm{pCO}_{2} 5.44 \mathrm{kPa}$. CT pulmonary angiogram was negative for pulmonary embolism and demonstrated consolidation in the right lung in keeping with infection (figure 1). He was managed for severe community-acquired pneumonia. Despite 2 weeks of intravenous antibiotics and clinical resolution of pneumonia, he had ongoing dyspnoea on exertion and oxygen requirement. A repeat CT scan demonstrated improvement of the previously noted consolidation in the right lung. A two-dimensional transthoracic echocardiogram (TTE) revealed mildly reduced left ventricular function and no intracardiac shunts. Contrast-enhanced TTE using peripheral injection of agitated colloid solution showed multiple microbubbles in the left ventricle, appearing after the third cardiac cycle, suggestive of an intrapulmonary shunt (figure 2); confirming the suspected diagnosis of hepatopulmonary syndrome (HPS).

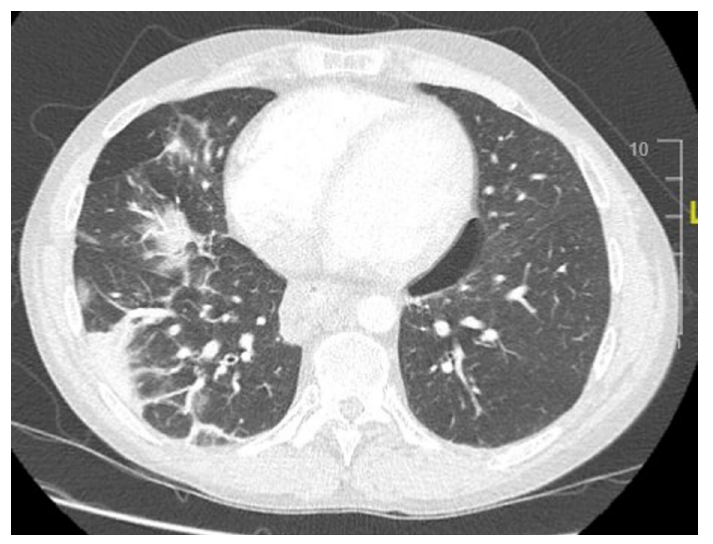

Figure 1 CT chest performed on admission demonstrating extensive consolidation throughout the right lung consistent with community-acquired pneumonia.

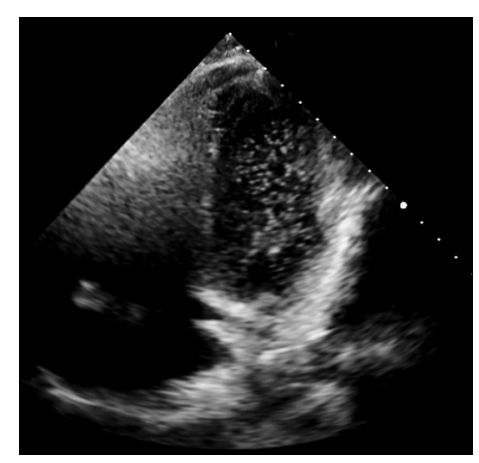

Figure 2 Contrast-enhanced two-dimensional transthoracic echocardiogram demonstrating multiple microbubbles in the left ventricle. The presence of microbubbles in the left heart occurred $\geq 3$ cardiac cycles after right heart appearance, thus, excluding intra-atrial shunting.

Following risk assessment, the patient was deemed unsuitable for long-term oxygen therapy (LTOT) as both he and his partner were active smokers and smoking cessation was deemed unlikely. He was discharged 1 month following admission after being weaned off oxygen and $\mathrm{PaO}_{2}$ was $7.6 \mathrm{kPa}$ on room air. At follow-up, his hypoxaemia was persisting $\left(\mathrm{PaO}_{2} 7.4 \mathrm{kPa}\right)$, but despite this, his dyspnoea had improved. Spirometry was consistent with a smoking history, with a forced expiratory volume in $1 \mathrm{~s}\left(\mathrm{FEV}_{1}\right) 51 \%$ of predicted, forced vital capacity (FVC) $77 \%$ of predicted and $\mathrm{FEV}_{1} / \mathrm{FVC}$ ratio of $67 \%$. The patient has committed to smoking cessation and is being considered for both LTOT and liver transplantation.

HPS is as a triad of liver disease, evidence of intrapulmonary vascular dilatations and pulmonary gas exchange abnormalities leading to arterial deoxygenation. ${ }^{1}$ When evaluating the hypoxaemic

\section{Learning points}

Hepatopulmonary syndrome (HPS) should be considered in all patients with known liver disease and unexplained hypoxaemia.

- Management options in HPS are limited; longterm oxygen therapy (LTOT) is beneficial. Liver transplantation remains the treatment of choice for HPS with complete resolution expected. Severe hypoxaemia due to HPS $\left(\mathrm{PaO}_{2}<8.0 \mathrm{kPa}\right)$ warrants a higher priority for transplantation.

- Ongoing cigarette smoking is a contraindication to both LTOT and liver transplantation. 
cirrhotic patient consideration of common pathologies including infection, chronic obstructive pulmonary disease, cardiac failure, ascites and anaemia is essential. In this case, the degree of hypoxaemia and its persistence despite resolution of infection prompted further evaluation and identification of HPS. Platypnoea and orthodeoxia are suggestive, but not pathognomonic, features of HPS and were not assessed in our patient. ${ }^{2}$ Our patient likely had compensated chronic hypoxaemia prior to presentation which was significantly exacerbated by infection. HPS often presents insidiously and may be precipitated by mild liver disease; therefore, a high suspicion of index is essential. ${ }^{2}$ LTOT is a recommended supportive measure in HPS. ${ }^{1-3}$ However, as in this case, contraindications to LTOT may be present; careful risk-benefit assessment must be undertaken. Liver transplantation is the only effective known treatment option with significant improvement in hypoxaemia in the majority of patients. ${ }^{23}$
Contributors $\mathrm{MO}$ and SM wrote up the case details and performed the literature search. SA was involved in clinical case management and evaluated the final manuscript.

Funding The authors have not declared a specific grant for this research from any funding agency in the public, commercial or not-for-profit sectors.

Competing interests None declared.

Patient consent for publication Obtained.

Provenance and peer review Not commissioned; externally peer reviewed.

ORCID iD

Meraj Ondhia http://orcid.org/0000-0001-9049-0338

\section{REFERENCES}

1 Krowka MJ. Hepatopulmonary syndromes. Gut 2000:46:1-4.

2 Ho V. Current concepts in the management of hepatopulmonary syndrome. Vasc Health Risk Manag 2008;4:1035-41.

3 Rodríguez-Roisin R, Krowka MJ. Hepatopulmonary syndrome--a liver-induced lung vascular disorder. N Engl J Med 2008;358:2378-87.

Copyright 2020 BMJ Publishing Group. All rights reserved. For permission to reuse any of this content visit https://www.bmi.com/company/products-services/rights-and-licensing/permissions/

BMJ Case Report Fellows may re-use this article for personal use and teaching without any further permission.

Become a Fellow of BMJ Case Reports today and you can:

- Submit as many cases as you like

Enjoy fast sympathetic peer review and rapid publication of accepted articles

- Access all the published articles

- Re-use any of the published material for personal use and teaching without further permission

Customer Service

If you have any further queries about your subscription, please contact our customer services team on +44 (0) 2071111105 or via email at support@bmj.com.

Visit casereports.bmj.com for more articles like this and to become a Fellow 